\title{
Inflammatory pseudo-tumours of the abdomen: plasma cell granulomas
}

\author{
JANE P. WU, ${ }^{1}$ EDUARDO J. YUNIS, GEORGE FETTERMAN, \\ WALTER F. JAESCHKE, AND ENID F. GILBERT
}

From the University of Wisconsin, Madison, Wisconsin, USA, and the University of Pittsburgh, Pittsburgh, Pennsylvania, USA.

SYNOPSIS Pseudo-tumours of the plasma cell granuloma type are reported in two patients. One was retroperitoneal and the other intraabdominal. Most of the cases of plasma cell granulomas described in the literature have been in the lung (Brunn, 1939; Childress and Adie, 1950; Cotton, 1952; Umiker and Iverson, 1954; Lane, Krohn, Kolozai, and Whitehead, 1955; Liebow and Hubbell, 1956; Titus, Harrison, Clagett, Anderson, and Knaff, 1962; Mason, Keats, and Baker, 1963; Wentworth, Lynch, Fallis, Turner, Lowden, and Conen, 1968; Bahadori and Liebow, 1973). A retroperitoneal site has not to our knowledge been reported previously. The postinflammatory nature of such lesions and the significance of a previous history of abdominal surgery are emphasized. It is important to be aware of such benign lesions which may simulate malignant tumours so that unnecessary radical treatment can be avoided.

Inflammatory pseudo-tumours can simulate true neoplasms both clinically and morphologically. Few such cases, however, have appeared in the literature and most of them have been in the lung and upper respiratory tract (Ash, Beck, and Wilkes, 1964). The only cases reported from the abdomen were one in the liver described by Pack and Baker (1953) and recently a gastric lesion reported by Soga, Saito, Suzuki, and Sakai (1970).

This paper reports two cases observed in the abdomen. One was a large pseudo-tumour of the retroperitoneum; this site has not been previously reported. The second was in the lesser sac of the peritoneal cavity.

\section{Case Reports}

\section{CASE I}

The first patient was a 60 -year-old white female and the wife of a farmer. She was admitted to the University of Wisconsin Hospitals for evaluation and treatment of bullous pemphigoid. During her physical examination, a large abdominal mass was noted. She had been aware of a sensation of a large

${ }^{1}$ Address for reprints: Dr Jane P. Wu, Department of Pathology, University of Wisconsin School of Medicine, Madison, Wisconsin, 53706.

Received for publication 10 September 1973. mass on the left side of the abdomen for the last three years. Her past history disclosed numerous abdominal operations including three Caesarean sections, a cholecystectomy, and removal of a 'benign' uterine tumour approximately 20 years previously.

The laboratory data showed a normal blood count and an unremarkable urine analysis. The SMA-12 evaluation of blood chemistry was within normal limits. A barium enema, upper gastrointestinal series, and an intravenous pyelogram all showed evidence of an intraabdominal mass which appeared to be extrinsic to the abdominal viscera.

At the time of the laparotomy, a large retroperitoneal tumour was found which was adherent to the lower pole of the left kidney. The kidney, therefore, was removed along with the tumour. The patient recovered uneventfully and there has been no recurrence of the lesion two years after surgery.

The resected specimen contained the left kidney with a tumour which was attached to the lower pole by dense fibrous tissue. The kidney could be separated from the tumour by stripping the capsule. The mass was solitary, well encapsulated, and ovalshaped with a smooth, bulging, and fibrous surface and a firm consistency (fig 1). It measured $14 \times 10$ $\times 10 \mathrm{~cm}$ and weighed $450 \mathrm{~g}$. The cut surface bulged slightly and was glistening white to pale tan in colour 


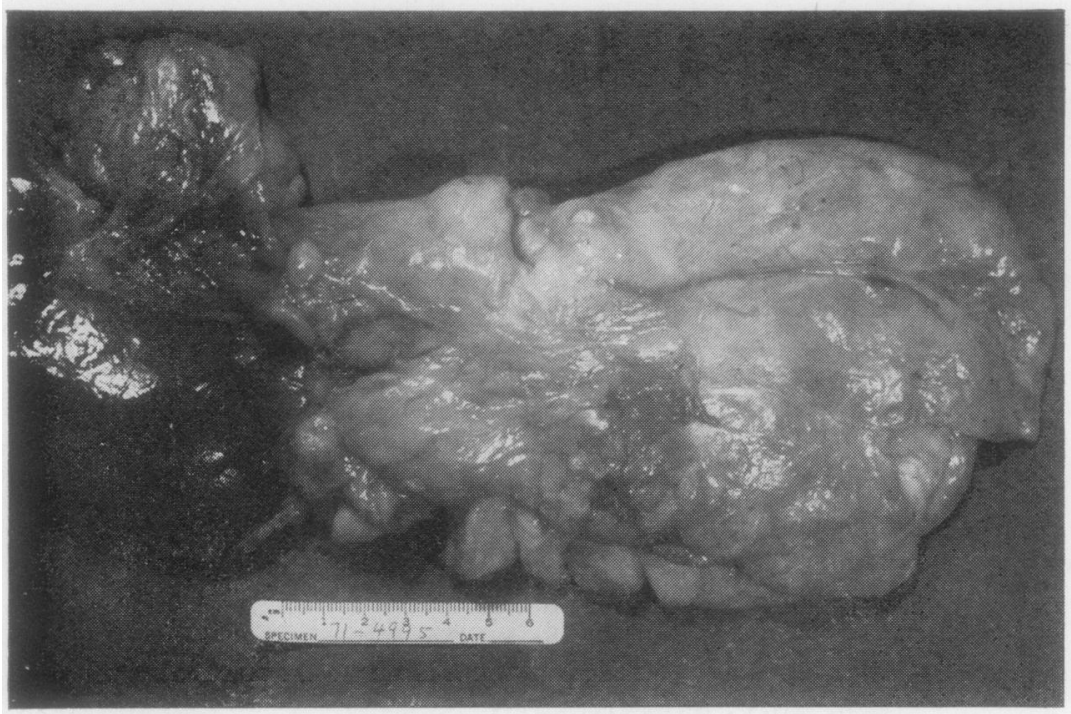

Fig 1 Gross appearance of the encapsulated retroperitoneal pseudotumour found in the first patient, with attached kidney on the left side.

with fine strands of fibrous tissue coursing through the mass. No hemorrhage or necrosis was visible (fig 2).

The microscopic examination revealed an overall pattern of a loose myxoid matrix in which were bundles of collagenous fibres separated by spaces, some of which resembled adipose tissue (fig 3). There were sparsely scattered stellate and spindleshaped cells of fibroblastic type. In addition to the loose and hypocellular background, there were scattered aggregates of plasma cells and lymphocytes which were mostly present in small clumps. The plasma cells contributed a predominant proportion; $;$ 는 many of them contained Russell bodies. Mitoses $\overrightarrow{0}$ were not present. The distribution of the plaspa $\mathrm{a}$ cells strongly suggested an inflammatory lesiô.

Sudan III and oil-red-O stains demonstrated onf very small amounts of lipid droplets around the blood vessels. Those spaces resembling adipose tissue with the haematoxylin and eosin stains were $\frac{}{\circ}$ completely devoid of lipid. The trichrome stains $\cong$ confirmed the fibroblastic nature of the collagenousô을

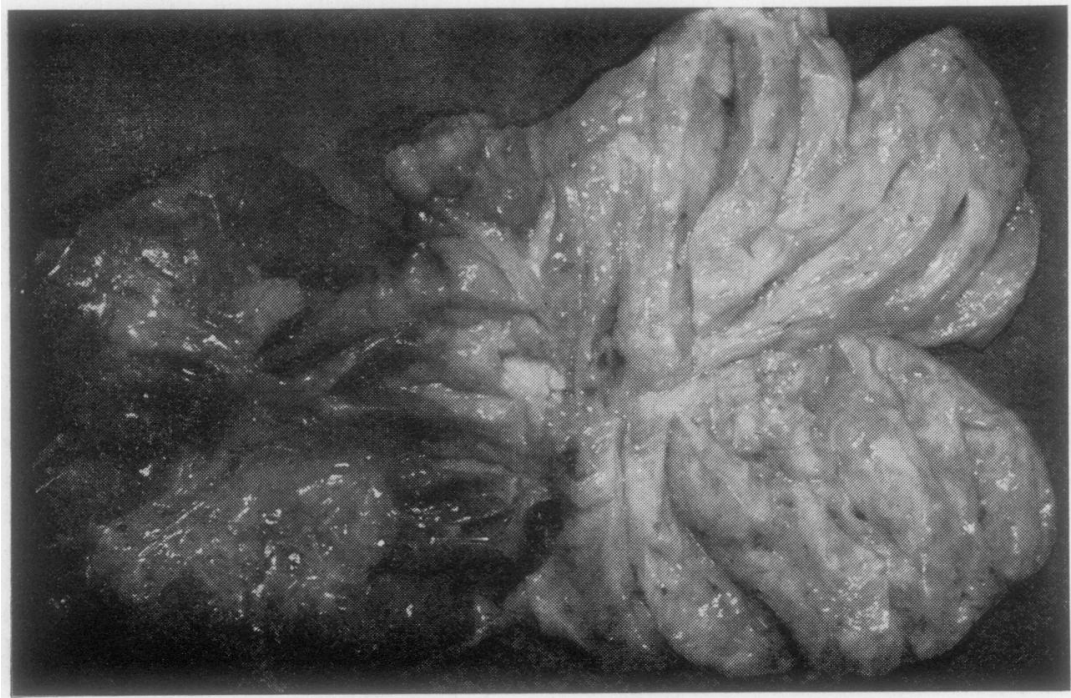

Fig 2 Cut surface of the retroperitoneal pseudotumour and attached kidney. 


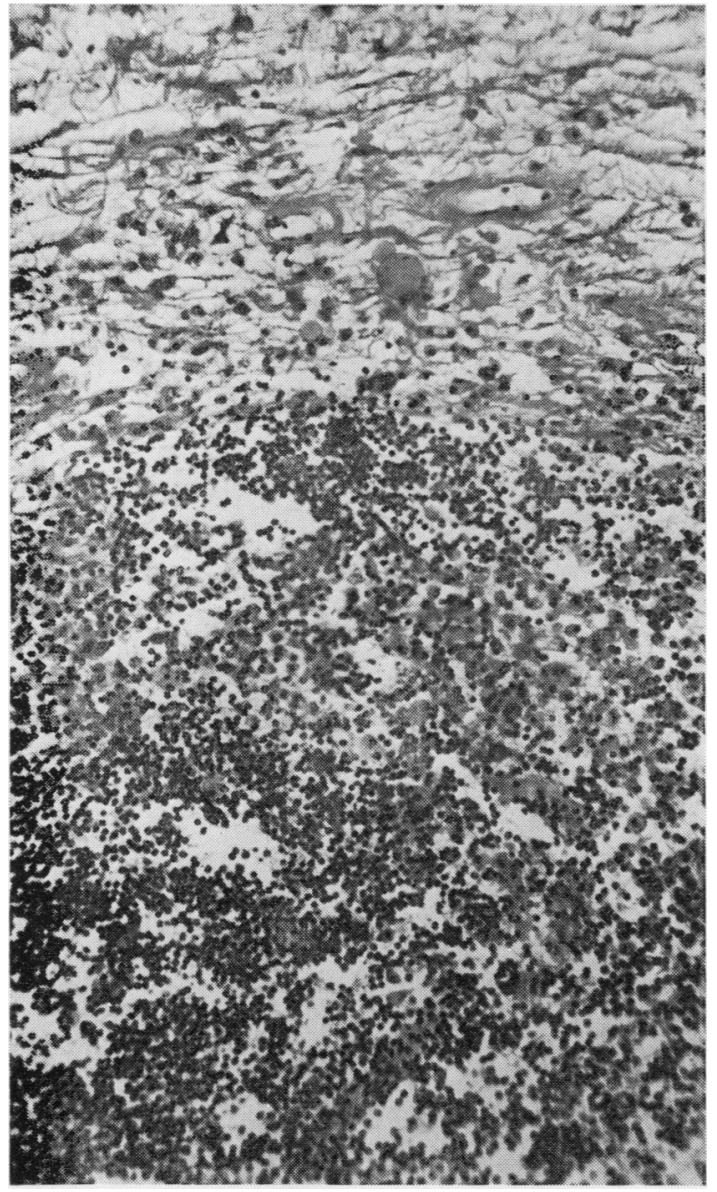

Fig 3 Microscopic section of the retroperitoneal pseudo-tumour showing clumps of lymphocytes and plasma cells with Russell bodies in a loose myxofibrous stroma in which are a few stellate and spindle-shaped fibrocytes. $H \& E \times 260$.

bundles. The Alcian blue and PAS stains were negative.

The electron microscopic studies revealed the presence of abundant collagen and plasma cells which appeared to be mature and non-neoplastic.

\section{CASE 2}

The second patient was a 14-year-old girl admitted to the children's Hospital of Pittsburgh on 24 July, 1967 because of vomiting and weight loss for five months. A ruptured appendix had been removed nine years earlier and a large quantity of pus was removed from the pelvis and the right lower quadrant of the abdomen. One year before her admission she began to experience intermittent burning pain in the epigastric region. On admission, an abdominal mass was palpated in the right upper quadrant and an upper gastrointestinal series showed an extrinsic mass over an area of the antrum of the stomach causing partial obstruction. At laparotomy, a huge mass was found in the lesser sac involving the lower end of the stomach, including the antrum and extending into the jejunum and transverse colon. The distal half of the stomach and portions of the transverse colon, jejunum, and pancreas were removed with the tumour. A gastro-duodenostomy, a jejuno-jejunostomy, and colo-colostomy were performed. Four and one half years after the operation the patient is in good health and able to take part in all activities that interest her.

The gross specimen was a $7 \mathrm{~cm}$ globular, firm but rubbery, gray-tan, fibrous tissue mass, with attached segments of stomach, colon, jejunum, pancreas, and greater omentum (fig 4). The serosa of the gastric antrum, pylorus, transverse colon, and jejunum was tenaciously bound to the mass. The wall of the stomach in this area was thick and tough. The overlying gray-tan granular pyloris mucosa was thickened and granular forming nodules up to $0.5 \mathrm{~cm}$ in diameter. Microscopically, the mass was composed of loose to dense fibrous tissue and scattered inflammatory cells (fig 5) with small lymphoid aggregates. It involved the wall of the stomach but not the mucosa except for focal granular disarray. Lymphocytes and plasma cells with Russell bodies were focally prominent (fig 6). In places, plasma cells were arranged in rows between bundles of fibrous tissue. Nodular proliferation of oedematous connective tissue found in areas suggested a fibrous or neural tumour (fig 7); however, the lesion was considered to be an inflammatory pseudo-tumour. Electron microscopic studies showed non-neoplastic plasma cells and abundant collagen. No viral particles were seen.

\section{Discussion}

Pseudo-tumours are usually large, solitary, discrete, firm, grayish-white to yellowish-tan masses, well demarcated from the surrounding tissues. The orbital pseudo-tumour (chronic granuloma) is more typical of a granulomatous lesion, usually is not a well circumscribed or encapsulated tumour, and will, therefore, not be included in this discussion.

Microscopically, three subtypes have been proposed in the lung: (1) sclerosing haemangioma in which the vascular component is predominant (Liebow and Hubbell, 1956); (2) xanthogranuloma with a prominent histiocytic component (Umiker and Inverson, 1954); and (3) plasma cell granuloma which is a well circumscribed fibroblastic proli- 


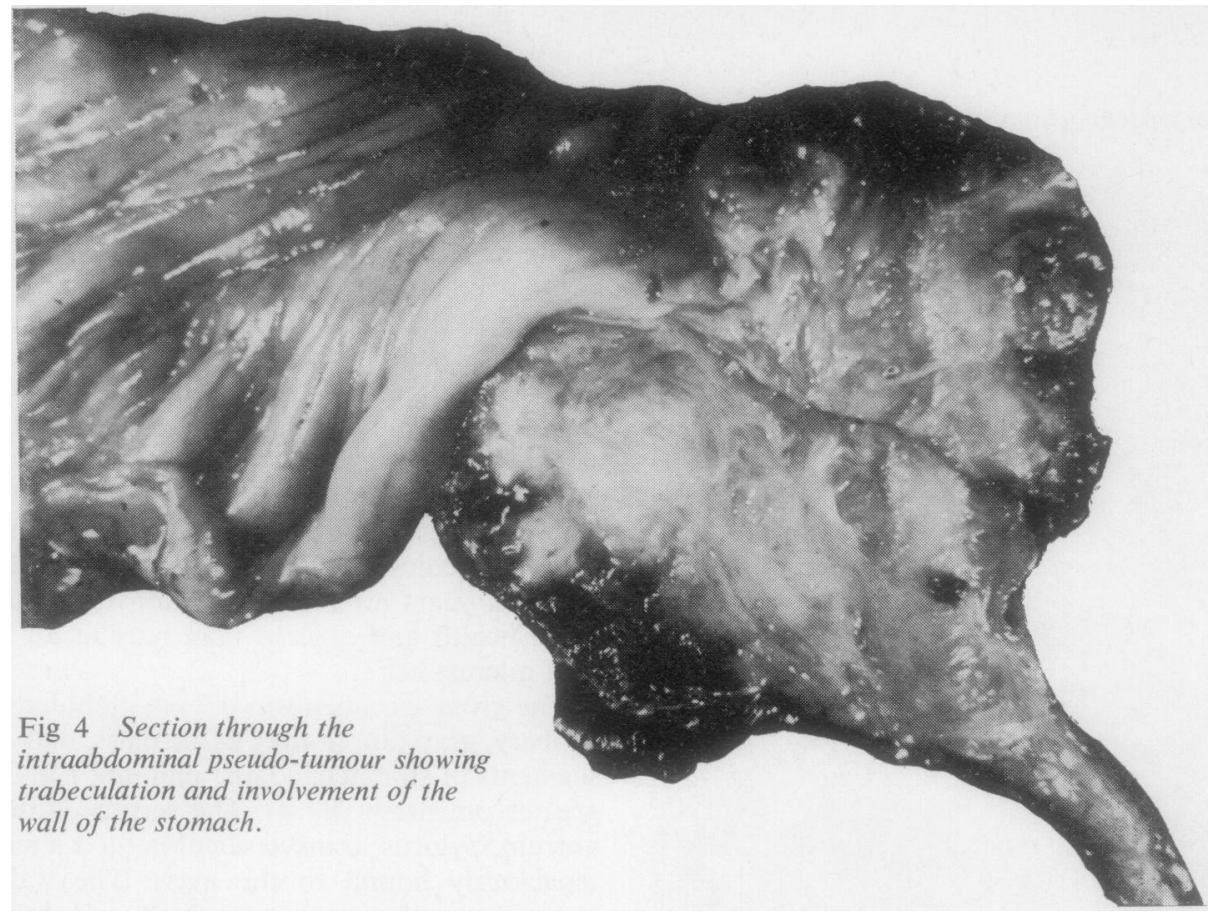

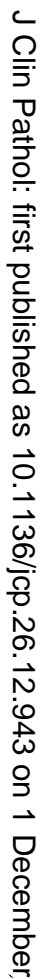

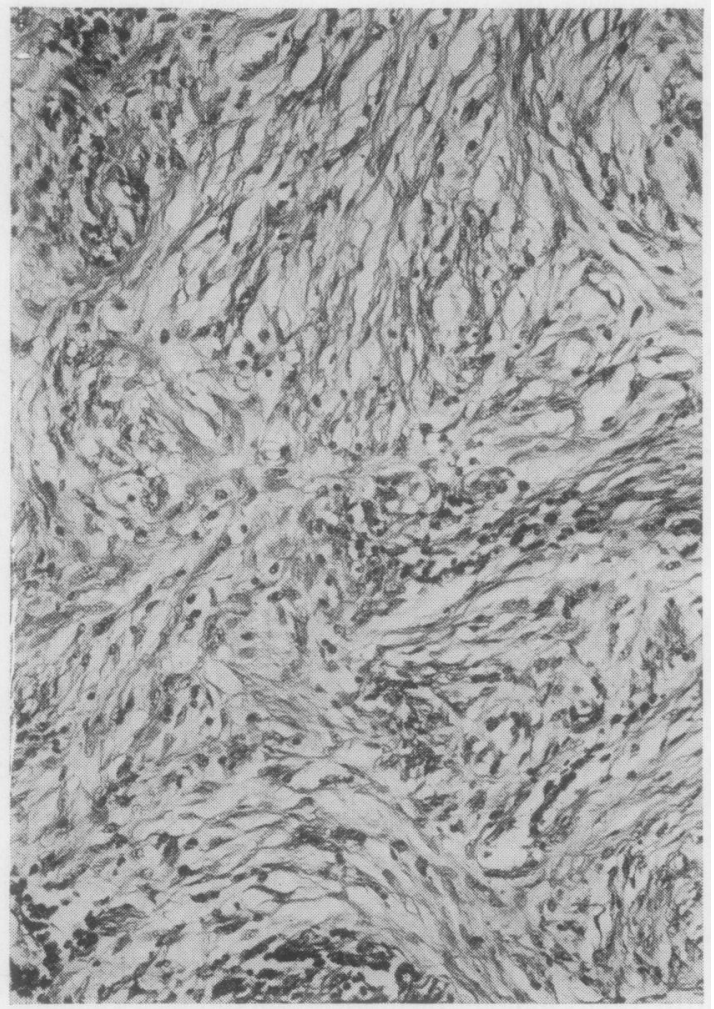

Fig 5 Fibrous tissue and some inflammatory cells are seen in this field from the intraabdominal pseudotumour removed from the second patient. $H \& E \times 115$.

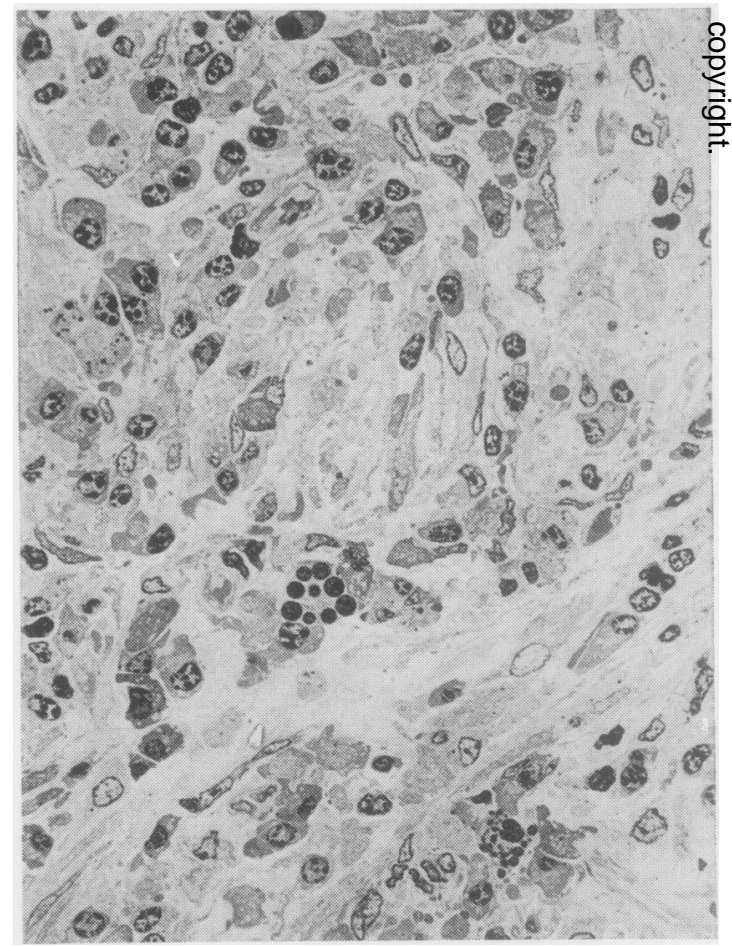

Fig 6 This light microscopic picture of the intraabdominal pseudo-tumour illustrates the plasma cells, Russell bodies, and other cellular elements. One micron section of material embedded in Epon-araldite stained with toluidine blue. $\times 475$.

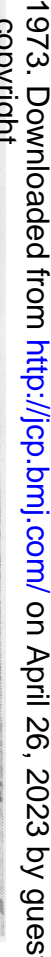

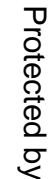




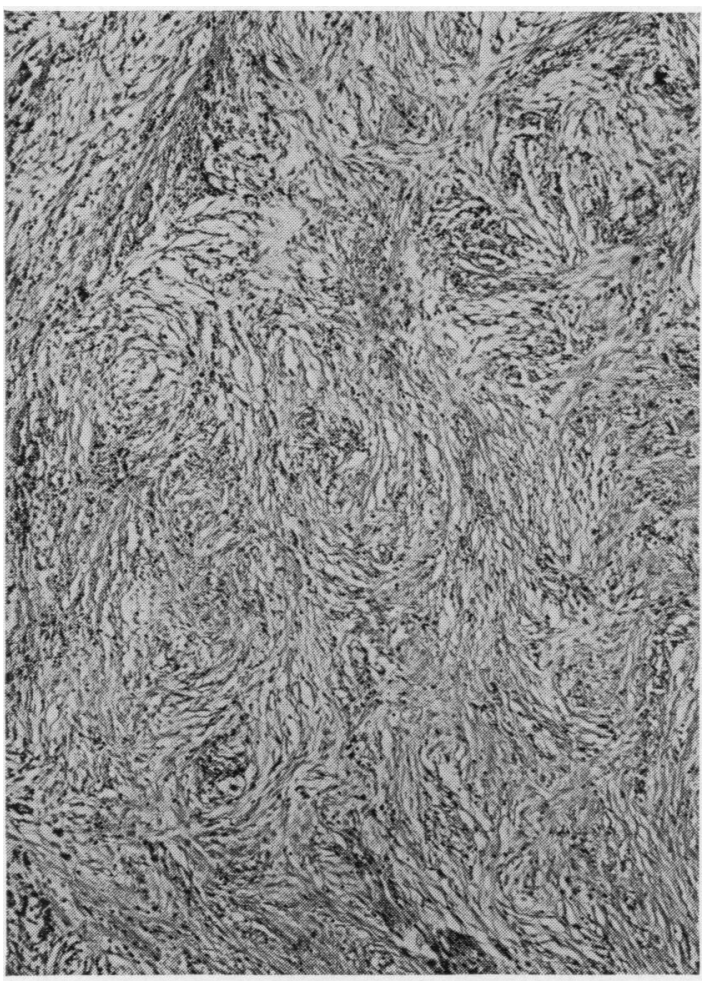

Fig 7 The nodular arrangement of loose, fibrous tissue seen in areas such as this suggested a neoplasm. Same case as figures 4, 5, and 6. H\&E $\times 46$.

feration intermixed with inflammatory cells with plasma cells predominating.

The exact pathogenesis of pseudo-tumours is not clear. However, there is usually a history of preceding inflammation (Umiker and Inverson, 1954; Mason et al, 1963). Some pulmonary cases have been attributed to a previous thoracotomy and in other cases a history of an antecedent respiratory infection including postnasal drips, chronic cough, and upper respiratory infection has been obtained. Almost all investigators stress the importance of chronic unresolved pneumonitis as the major aetiological factor (Gerami et al, 1968).

In the case published by Soga et al (1970), in which a large plasma cell granuloma of the stomach was described, there was no previous abdominal operation, but there was a mucosal ulcer at the centre of the tumour. The fibrous and inflammatory process involved the submucosa, the muscular layers, and the subserosal region and extended irregularly into the surrounding tissue. The process seemed to originate in the submucosa. From their description, it is our impression that the presence of a gastric ulcer was not merely coincidental or sequential to the development of the tumour, but probably represented the underlying cause of the reactive process and resulted in the formation of a pseudo-tumour.

The gross appearance of both our cases suggested a neoplasm. The differential diagnosis based on the histological appearances of the lesion of the first patient included consideration of myxomatous benign soft tissue tumours, myxoliposarcoma, and xanthogranuloma. The negative fat stains eliminated the lipomatous and xanthomatous varieties and the Alcian blue stain did not show hyaluronic acid which is usually present in myxoma.

On frozen section and low-power examination of haematoxylin and eosin-stained sections, the streaming arrangement of round cells along bands of fibrous tissue present in the lesion from the second patient suggested a carcinoma of the stomach.

The histological appearance in other areas was suggestive of a connective tissue tumour.

Plasma cell granuloma is not an ideal term for these lesions but is useful because it emphasizes their benign plasma cell content. However, there should be no difficulty in differentiating a reactive plasmacytosis from a true neoplastic plasmacytoma in most instances. In any chronic inflammatory process, the degree of plasmacytic or lymphocytic infiltration can vary greatly and does not necessarily indicate a different process. We have chosen to classify these lesions as postinflammatory pseudotumours to emphasize their suspected pathogenetic mechanisms and their possible confusion with a true neoplasm. Most of these cases run a long course which sometimes is helpful in ruling out a malignant process.

\section{References}

Ash, J. E., Beck, M. R., and Wilkes, J. D. (1964). Tumors of the upper respiratory tract and ear. In Atlas of Tumor Pathology, Fascicles 12 and 13, p. 185. Armed Forces Institute of Pathology, Washington, D.C.

Bahadori, M., and Liebow, A. A. (1973). Plasma cell granulomas of the lung. Cancer (Philad.), 31, 191-208.

Brunn, H. (1939). Two interesting benign lung tumours of contradictory histopathology: remarks on the necessity for maintaining the chest tumour registry. $J$. thorac. cardiovasc. Surg., 9, 119-131.

Childress, W. G., and Aldie, G. C. (1950). Plasma cell tumours of the mediastinum and lung: report of two cases.J. thorac. cardiovasc. Surg., 19, 794-799.

Cotton, B. H., and Penido, J. R. F. (1952). Plasma cell tumours of the lung. Dis. Chest, 21, 218-221.

Gerami, S., Moseley, T. M., and Miller E. K. (1968). Inflammatory pseudotumours of the lung: a report of two cases and brief review of the literature. Sth. med.J. (Bgham, Ala.), 61, 395-399.

Lane, J. D., Krokn, S., Kolozai, W., and Whitehead, R. E. (1955). Plasma cell granuloma of the lung. Dis. Chest, 27, 216-221.

Liebow, A. A., and Hubbell, D. S. (1956). Sclerosing hemangioma (Histiocytoma xanthoma) of lung. Cancer (Philad.), 9, 53-75. 
Mason, W. E., Keats, T. E., and Baker, G. F. (1963). Inflammatory pseudotumor of the lung. Radiology, 81, 824-827.

Pack, G. T., and Baker, H. W. (1953). Total right hepatic lobectomy: report of a case. Ann. Surg., 138, 253-258.

Soga, J., Saito, K., Suzuki, N., and Sakai, T. (1970). Plasma cell granuloma of the stomach: a report of a case and review of the literature. Cancer (Philad.), 25, 618-625.

Titus, J. L., Harrison, E. G., Clagett, O. T., Anderson, M. W., and
Knaff, L. J. (1962). Xanthomatous and inflammatory pseudo- $\stackrel{2}{=}$ tumours of the lung. Cancer (Philad.), 15, 522-538.

Umiker, W. O., and Iverson, L. (1954). Postinflammatory 'tumours' of the lung: report of four cases simulating xanthoma, fibroma, $\overrightarrow{\overline{\vec{r}}}$ or plasma cell tumour. J. thorac. cardiovasc. Surg., 28, 55-63. क)

Wentworth, P., Lynch, M. J., Fallis, J. C., Turner, J. A. P., Lowden, J. A., and Conen, P. E. (1968). Xanthomatous pseudotumour of lung: a case report with electron microscope and lipid studies. Cancer (Philad.), 22, 345-355.

\section{The November 1973 Issue}

\section{THE NOVEMBER 1973 ISSUE CONTAINS THE FOLLOWING PAPERS}

Benefit and mischief from commensal bacteria R. E. O. WILLIAMS

An assessment of the usefulness of dip slides in a children's hospital T. L. SHRESTHA AND N. E. G. RICHARDSON

The ortho-nitrophenol (ONPG) test and acid from lactose in Gram-negative genera S. P. LAPAGE, ANDROULLA EFSTRATIOU, AND L. R. HILL

Non-flagellate Pseudomonas aeruginosa in pathological material F. W. LEE

A guide to the histological identification of fungi in tissues P. P. ANTHONY

Epidemiological and quantitative relationships between mesothelioma and asbestos on Tyneside T. ASHCROFT

Types of 'reticulin' antibodies detected in human sera by immunofluorescence MARIO RIZZETTO AND DEBORAH DONIACH

Quantitative immunoelectrophoretic analysis of the plasma proteins in the sol phase of sputum from patients with chronic bronchitis H. C. RYLEY AND T. D. BROGAN

Stability of freeze-dried plasma prepared from patients on oral anticoagulants MILICA BROzović, D. J. HOWARTH, L. P. Van HALEM VISSER, AND E. A. LOELIGER

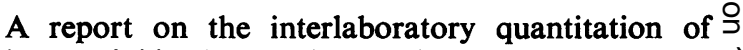
haemoglobin $A_{2}$ and haemoglobin $F$ J. M. WHITE AND S. M. LEWIS

Acute haemolytic anaemia associated with poly- $\frac{0}{3}$ agglutinability of red cells T. BIRD AND J. STEPHENSON

An automated method for the microbiological assa of serum pyridoxal R. E. DAVIS, B. J. SMITH, AND D. H. CURNOW

The Leeds regional quality control scheme for clinical biochemistry: A progress report A. T. HOWARTH, R. L. NOBLE, R. B. PAYNE, A. E. STEEL, AND P. $R$. TEASDALE

Haematology-trends and opportunities E. K. BLACKBURN

Men and machines N. H. MARTIN

\section{Technical methods}

A serial whole-organ slicing technique for examining surgically resected breasts J. DOUGLAS DAVIES, G. ROBERTS, AND P. J. RICHARDSON

Bedside control of heparin therapy by a simple whole blood clotting method. C. COTTON KENNEDY AND M. J. ROCKS

Letters to the Editor

Book reviews/Notices

Copies are still available and may be obtained from the PUBLISHING MANAGER, BRITISH MEDICAL ASSOCIATION, TAVISTOCK SQUARE, WC1H 9JR, price $£ 1.05$ 